\title{
Analisis Kritis Atas Rendahnya Pembiayaan Berbasis Bagi Hasil Pada BMT di Jepara
}

\author{
Fatkur Rohman Ahmad \\ BMT Lima Satu Jepara \\ faturbmtlisa@gmail.com
}

\begin{abstract}
The purpose of this study is to identify factors influencing the low volume of profit sharing-based financing products of BMT Jepara. This study uses interviews with several related parties, including: the academician, practitioners, and customers. The problem of low profit sharing-based financing products in this study is viewed from three aspects: internal, external, and regulation aspects. Based on the results of the study, from the internal aspect of BMT, the problem of profit sharing-based financing productst is caused by six factors, namely: High risk, Lack of quality and quantity of Human Resources, Complicated handling, No product innovation, Asymmatric information, and Lack of socialization. Meanwhile, the external aspects of BMT is caused by three factors, namely: Moral hazard, Lack of community's knowledge on Islamic banking products, and Low of demand. Finally, from the aspect of the regulation, the low profit sharing-based financing products caused by lack of support from the regulator. Based on the results of this study, BMT is expected to develop and innovate its products in order to minimize the risk, as well as to socialize to the community so that people know the products of BMT. To the customers of BMT are expected to better understand products of the Syariah Banking. The Regulators are expected to regulate supporting policies to encourage the growth of profit sharingbased financing products so that the Islamic Bank would enhance the economic welfare of the Islamic society in the future.
\end{abstract}

Keywords: Profit Sharing Financing, BMT, Factors, Internal BMT, External BMT, Regulation.

\begin{abstract}
Abstrak
Tujuan dari penelitian ini adalah untuk mengidentifikasi faktor-faktor yang mempengaruhi rendahnya volume produk pembiayaan berbasis bagi hasil di BMT Jepara. Penelitian ini menggunakan wawancara dengan beberapa pihak terkait, termasuk: Akademisi, Praktisi, Anggota. Masalah rendahnya produk pembiayaan berbasis bagi hasil dalam penelitian ini dilihat dari tiga aspek: Aspek Internal, Eksternal, dan Regulasi. Berdasarkan hasil penelitian, dari aspek internal BMT, masalah rendahnya produk pembiayaan berbasis bagi hasil disebabkan oleh enam faktor, yaitu: Risiko tinggi, Kurangnya kualitas dan kuantitas Sumber Daya Manusia, Penanganan yang rumit, Tidak ada inovasi produk, Informasi yang disembunyikan, dan Kurangnya sosialisasi. Sementara itu, aspek eksternal BMT disebabkan oleh tiga faktor, yaitu: Bahaya moral, Kurangnya pengetahuan masyarakat tentang produk perbankan syariah, dan Rendahnya permintaan. Akhirnya, dari aspek regulasi, rendahnya produk pembiayaan berbasis bagi hasil disebabkan oleh kurangnya dukungan dari regulator. Berdasarkan hasil penelitian ini, BMT diharapkan mengembangkan
\end{abstract}


dan berinovasi produk-produknya untuk meminimalkan risiko, serta untuk bersosialisasi kepada masyarakat sehingga masyarakat mengetahui produkproduk BMT. Bagi para Anggota BMT diharapkan untuk lebih memahami produk- produk Koperasi Syariah. Para regulator diharapkan untuk mengatur kebijakan pendukung untuk mendorong pertumbuhan produk pembiayaan berbasis bagi hasil sehingga Koperasi Syariah akan meningkatkan kesejahteraan ekonomi masyarakat Islam di masa depan.

Kata kunci: Pembiayaan Bagi Hasil, BMT, Faktor, Internal BMT, Eksternal BMT, Regulasi.

\section{PENDAHULUAN}

Secara teoritis prinsip bagi hasil dan risiko merupakan inti atau karakteristik utama dari kegiatan koperasi syari'ah. Akan tetapi dalam kegiatan pembiayaan bagi hasil dan risiko produk musyarakah dan mudharabah kurang diminati dalam kegiatan pembiayaan, Hal ini disebabkan oleh karena tingkat risiko pembiayaan berbasis bagi hasil sangat tinggi (hight risk) dan pengembaliannya tidak pasti. Rendahnya pembiayaan berbasis bagi hasil dalam perbankan syariah telah menjadi masalah klasik dan belum mendapatkan perhatian yang proporsional oleh praktisi maupun akademisi, Dalam banyak kasus, antara koperasi dan Anggota sama-sama tidak memahami esensi sistem bagi hasil, kurangnya sosialisasi dan banyak lagi faktor sehingga cenderung pembiayaan dengan sistem bagi hasil ini rendah dan kurang diminati Anggota.

Disinilah pentingnya kita mengkaji dan menemukan konsep yang ideal dari prinsip bagi hasil dan risiko (Profit and Loss Sharing) dalam koperasi syari'ah, agar kedua belah pihak baik koperasi maupun Anggota peminjam dapat menjalankan usaha atau bisnisnya dengan aman tanpa ada kekhawatiran atau ketakutan yang berlebihan, sehingga produk berbasis bagi hasil akan tetap menjadi produk pembiayaan yang utama bagi koperasi syari'ah pada masa yang akan datang.

Beberapa penelitian terkait rendahnya pembiayaan bagi hasil dilakukan diantaranya Ascarya yang melakukan penelitian terhadap Perbankan Syariah Indonesia, dengan menggunakan analisis ANP menunjukkan bahwa terdapat beberapa faktor yang menyebabkan pembiayaan berbasis bagi hasil rendah, diantaranya adalah karena adanya aspek internal bank, nasabah, regulasi, pemerintah dan intitusi lain ( Ascarya, 2005: 18).

Penelitian lain dilakukan oleh Pamungkas Aji dengan melakukan identifikasi faktor yang mempengaruhi rendahnya pembiayaan bagi hasil perbankan syariah di kota malang, dari hasil penelitian menunjukkan bahwa total nasabah pada BRI Syariah Malang memiliki minat yang rendah terhadap pembiayaan musyarokah dan mudharabah, faktor 
penyebabnya adalah internal perbankan syariah, Anggota itu sendiri, pemerintah serta institusi lain ( Pamungkas Aji, 2013;14).

Dari penelitian terdahulu tersebut menunjukkan bahwa terdapat beberapa factor yang menyebabkan pembiayaan berbasis bagi hasil rendah, diantaranya adalah karena adanya aspek regulasi dan aspek internal perbankan. faktor penyebab lain adalah internal perbankan syariah, Anggota itu sendiri dan regulasi juga pemerintah serta institusi lain.

Selain karena alasan tersebut di atas, terdapat hal lain yang menjadi gap research dalam penelitian ini, secara teoritis Lembaga Keuangan Syariah operasionalnya menggunakan sistem bagi hasil sebagai core bassic bisnisnya, seharusnya pembiayaan dengan basis bagi hasil ini lebih banyak mewarnai operasional Lembaga Keuangan Syariah, namun kenyataannya signifikansi pembiayaan bagi hasil ini sangat lemah (Muhammad, 2005;108) sehingga antara konsep teori dengan praktek terjadi perbedaan. Hal ini dapat dilihat dari riset awal yang dilakukan oleh peneliti dengan tujuan untuk mengetahui seberapa rendah pembiayaan berbasis bagi hasil yang merupakan bahan telaah dan sebagai kajian terkait untuk melakukan analisa selanjutnya.

\section{Tabel 1}

Komposisi Pembiayaan di PBMT Jepara Tahun 2017-2019 (dalam Ribuan Rupiah)

\begin{tabular}{|c|c|c|c|c|}
\hline \multicolumn{2}{|c|}{ PRODUK PEMBIAYAAN } & 2017 & 2018 & 2019 \\
\hline \multirow{2}{*}{$\begin{array}{l}\text { Bagi } \\
\text { Hasil }\end{array}$} & Mudharabah & $7,406,507$ & $8,097,591$ & $9,940,545$ \\
\hline & Musyarokah & $2,309,311$ & $2,098,695$ & $2,540,725$ \\
\hline \multirow{8}{*}{$\begin{array}{l}\text { Non } \\
\text { Bagi } \\
\text { Hasil }\end{array}$} & Murabahah & $22,343,605$ & $25,822,681$ & $29,144,756$ \\
\hline & Ba'I Bi'saman Ajil & $1,590,721$ & $1,764,079$ & $1,706,546$ \\
\hline & mmq Bil Ba'i & - & $6,184,824$ & $12,344,162$ \\
\hline & Hawalah & $1,404,510$ & $1,388,792$ & $1,453,294$ \\
\hline & Ijaroh & $13,882,959$ & $15,982,055$ & $13,411,025$ \\
\hline & Rohn & $18,795,757$ & $20,633,937$ & $26,841,002$ \\
\hline & Qordlu Bisyarti Rohn & $24,045,630$ & $28,509,709$ & $32,914,362$ \\
\hline & Qordlu Hasan & $2,011,909$ & $1,803,430$ & 2,297,139 \\
\hline \multicolumn{2}{|c|}{ Sub-Total Bagi Hasil } & $9,715,818$ & $10,196,286$ & $12,481,270$ \\
\hline \multicolumn{2}{|c|}{ Sub-Total Non-Bagi Hasil } & $84,075,091$ & $102,089,507$ & $120,112,286$ \\
\hline \multicolumn{2}{|l|}{ Total } & $93,790,909$ & $112,285,793$ & $132,593,556$ \\
\hline
\end{tabular}

Sumber Data : laporan PBMT Jepara ( Diolah)

Berdasar Tabel di atas menunjukkan bahwa pembiayaan berbasis Bagi hasil pada PBMT Jepara komposisinya hanya 9,4\%, hal ini berbanding terbalik dengan pembiayaan non bagi hasil yang komposisinya sebesar $90,5 \%$ hal ini menjadi sebuah pertanyaan besar 
yang perlu untuk dikaji lebih dalam mengenai rendahnya pembiayaan berbasis bagi hasil. karena jika kondisi tersebut terus terjadi maka bukan tidak mungkin pembiayaan berbasis bagi hasil pada PBMT Jepara yang menjadi ikon utama dan ciri khas dalam pembiayaan pada BMT akan berangsur hilang jika tidak di temukan solusi untuk perbaikan.

Berdasar penelitian yang dilakukan oleh peneliti sebelumnya, disimpulkan bahwa terdapat beberapa kelemahan dalam memberikan solusi dan memetakan faktor penyebab rendahnya pembiayaan berbasis bagi hasil yang menjadi penyebab belum dapat di terapkan sesuai dengan wilayah BMT di Kabupaten Jepara, diantarnya dalam penelitian terdahulu dilakukan dengan membandingan Bank - Bank Syariah dunia, dan memperbandingkan Bank-Bank Syariah di Indonesia, padahal karakteristik Bank dengan BMT sangatlah jauh berbeda, Bank menangani pembiayaan dengan kapasitas Usaha Kecil Menengah yang tentunya sudah Bankable, sedangkan BMT menangani pembiayaan dengan kapasitas Mikro yang tentunya belum Bankable. Hal ini yang menjadi perbedaan antara penelitian terdahulu dengan penelitian yang dilakukan oleh peneliti.

Dengan menggunakan gap Research dan didukung beberapa penelitian terdahulu juga disertai dengan data penelitian awal terkait komposisi pembiayaan di PBMT Jepara, belum ada strategi yang dapat diambil oleh BMT untuk meningkatkan porsi pembiayaan bagi hasil. Hal inilah yang menjadi daya tarik dan menjadi latar belakang peneliti untuk menganalisis lebih jauh tentang masalah Rendahnya Pembiayaan Berbasis Bagi Hasil pada BMT se-Kabupaten Jepara.

\section{KAJIAN LITERATUR}

\section{Sistem Bagi Hasil}

Bagi hasil menurut terminologi dikenal dengan profit sharing. Profit sharing diartikan pembagian laba. Sedangkan secara definitive profit sharing diartikan distribusi beberapa bagian laba pada para pegawai dari suatu perusahaan ( Muhammad, 2017 :25). Menurut Bank Indonesia bagi hasil adalah suatu prinsip pembagian laba yang diterapkan dalam kemitraan kerja, dimana porsi bagi hasil ditentukan pada saat akad kerjasama. Jika usaha mendapatkan keuntungan, porsi bagi hasil adalah sesuai kesepakatan namun jika terjadi kerugian maka porsi bagi hasil disesuaikan dengan kontribusi modal masing-masing pihak. Dasar yang digunakan dalam perhitungan bagi hasil adalah berupa laba bersih usaha setelah dikurangi dengan biaya operasional. Profit sharing (bagi hasil) pada dasarnya merupakan pembiayaan dengan prinsip kepercayaan dan kesepakatan murni antara kedua belah pihak atau lebih yaitu pemilik modal / investor (Kartika Soetopo, 2005 ;211). 
Ascarya menjelaskan pembiayaan musyarakah adalah kerjasama dimana dua atau lebih pengusahan bekerjasama sebagai mitra usaha dalam bisnis. Masing-masing pihak menyertakan modalnya dan ikut mengelola usaha tersebut. Keuntungan dan kerugian akan dibagi berdasarkan presentase penyertaan modalnya ( Ascarya, 2013;49). Sedangkan mudharabah adalah kerjasama usaha antara dua orang dimana pihak pertama (shohibul maal) menyediakan seluruh modal, sedangkan pihak lainnya menjadi pengelola (Syafii Antonio, 2001;90).

Pembiayaan mudharabah adalah pembiayaan atau penanaman dana dari pemilik dana (shahibul maal) kepada pengelola dana (mudharib) untuk melakukan kegiatan usaha tertentu yang sesuai dengan syariah, dengan pembagian bagi hasil usaha antara kedua pihak berdasarkan nisbah yang telah disepakati sebelumnya, dimana moda usaha seluruhnya berasal dari pihak shahibul maal atau pemilik dana, Sedangkan secara teknis, mudharabah didefinisikan sebagai akad kerja sama antara dua pihak dimana pihak pertama (shahibul maal) menyediakan 100\% modal sedangkan pihak lainnya menjadi pengelola (mudharib). Apabila dalam usahanya diperoleh keuntungan (profit) maka keuntungan tadi kemudian dibagi antara shahibul maal dan mudharib dengan prosentase nisbah atau rasio yang telah disepakati sejak awal perjanjian/kontrak. Sedangkan apabila usaha tersebut merugi maka kerugian tersebut akan ditanggung sepenuhnya oleh pihak shahibul maal sepanjang hal itu disebabkan oleh risiko bisnis (bussiness risk) dan bukan karena kelalaian mudharib / character risk ( Erni Susanna \& Annisa, 2010;468).

Metode bagi hasil terdiri dari dua sistem :

1. Bagi untung (Profit Sharing) adalah bagi hasil yang dihitung dari pendapatan setelah dikurangi biaya pengelolaan dana. Dalam sistem syariah pola ini dapat digunakan untuk keperluan distribusi hasil usaha lembaga keuangan syariah.

2. Bagi hasil (Revenue Sharing) adalah bagi hasil yang dihitung dari total pendapatan pengelolaan dana. Dalam sistem syariah pola ini dapat digunakan untuk keperluan distribusi hasil usaha lembaga keuangan syariah. Suatu koperasi syariah yang menggunakan sistem bagi hasil berdasarkan revenue sharing yaitu bagi hasil yang akan didistribusikan dihitung dari total pendapatan koperasi syariah sebelum dikurangi dengan biaya koperasi syariah, maka kemungkinan yang akan terjadi adalah tingkat bagi hasil yang diterima oleh pemilik dana akan lebih besar dibandingkan dengan tingkat suku bunga pasar yang berlaku.

Prinsip pembagian hasil usaha ada 2 yaitu Distribusi Hasil Usaha Berdasarkan Prinsip Bagi Hasil (Revenue Sharing) Dan Distribusi Hasil Usaha Berdasarkan Prinsip Bagi Untung (Profit Sharing). Penerapan 
distribusi hasil usaha dengan prinsip bagi untung (profit sharing) bukanlah hal yang mudah, karena pihak deposan harus siap menerima bagian kerugian apabila dalam pengelolaan dana mudharabah mengalami kerugian yang bukan akibat dari kelalaian mudharib sehingga uang yang diinvestasikan pada koperasi syariah menjadi berkurang (Wiroso, $2005 ; 120$ ).

\section{Faktor Yang Mempengaruhi Rendahnya Pembiayaan Berbasis Bagi Hasil}

Rendahnya pembiayaan bagi hasil atau dominasi pembiayaan nonbagi hasil pada prtofolio pembiayaan koperasi syariah ternyata merupakan fenomena global yang terjadi tidak hanya di lembaga keuangan syariah di Indonesia, melainkan terjadi pada lembaga keuangan syariah di seluruh dunia. lebih jauh lagi, fenomena ini terjadi tidak hanya di koperasi syariah yang baru atau belum lama berdiri (yang masih pada masa transisi), melainkan juga terjadi di koperasi syariah yang sudah cukup lama berdiri (yang sudah dianggap established).

Permasalahan penggunaan pembiayaan bagi hasil yang masih sangat rendah ini merupakan masalah yang tidak sederhana. Bahkan merupakan masalah yang memiliki multi dimensi. Beberapa pakar telah mencoba mengindentifikasi sumber-suber penyebab terjadinya masalah yang kelihatannya sulit diuraikan ini ( Ascarya, 2005 ; 23).

Adanya faktor-faktor tersebut, kemungkinan besar bisa mempengaruhi kebijakan koperasi syariah untuk mengeluarkan pembiayaan. Karena didalam koperasi syariah sangat memperhatikan prinsip-prinsip kehati-hatian (Hana, 2018). Dengan adanya prinsip kehatihatian ini juga bisa mempengaruhi porsi pembiayaan berbasis bagi hasil menjadi berkurang. Itu dikarenakan pembiayaan berbasis bagi hasil memiliki resiko yang cukup tinggi.

Tingginya faktor resiko ini yang menyebabkan rendahnya pembiayaan berbasis bagi hasil, namun meskipun tingkat resikonya sangat rendah, tetapi apabila tingkat resiko tersebut bisa ditekan, maka pembiayaan ini bisa berjalan dengan baik, salah satu faktor yang berpengaruh terhadap efektivitas pengendalian resiko adalah adanya sistem pengendalian resiko (Muhammad , $2004 ; 5$ ).

\section{PEMBAHASAN}

PBMT Jepara pada tahun 2012 anggota PBMT ada 10 anggota, dan pada tahun 2015 menjadi 12 anggota, terakhir pada tahun 2017 keanggotaan menjadi 14 BMT. Dalam penelitian ini, obyek yang diambil adalah BMT yang tergabung dalam PBMT Jepara. Sampai tahun 2019 di Kabupaten Jepara terdapat 39 BMT, dan yang bergabung dengan PBMT 
Jepara ada 14 BMT. Perkembangan BMT di Kabupaten Jepara secara keseluruhan nampak sebagaimana Tabel 2 berikut.

Tabel 2

Kondisi BMT Kabupaten jepara

\begin{tabular}{l|ll|l|l|l|l}
\hline \multirow{2}{*}{ No } & Uraian & \multicolumn{2}{l}{ Tahun } & \multicolumn{2}{l}{} \\
\cline { 3 - 6 } & & 2011 & 2012 & 2015 & 2019 \\
\hline 1 & Jumlah BMT & 12 & 30 & 37 & 39 \\
\hline 2 & $\begin{array}{l}\text { Jumlah BMT yang tergabung } \\
\text { dalamPBMTI Jepara }\end{array}$ & 5 & 10 & 12 & 14 \\
\end{tabular}

Sumber : Perhimpunan BMT Kabupaten Jepara Tahun 2019

\section{Hasil Wawancara}

Wawancara dilakukan pada bulan Juni-Juli 2020, dengan narasumber manager dari masing-masing BMT yang tergabung dalam PBMT Jepara, selain manager wawancara dilakukan kepada Anggota BMT yang sudah menggunakan layanan dan memanfaatkan pembiayaan pada BMT di Jepara. Dalam proses wawancara, peneliti menanyakan beberapa masalah yang terkait rendahnya pembiayaan berbasis bagi hasil, diantaranya pembiayaan di masing-masing BMT, mekanisme BMT dalam mengeluarkan pembiayaan, pembiayaan apa saja yang dikeluarkan oleh BMT komposisi masing-masing pembiayaan antara pembiayaan dengan bagi hasil dan non bagi hasil.

Hasil dalam penelitian mengenai informasi-informasi terkait rumusan masalah penelitian yaitu menganalisis penyebab rendahnya pembiayaan berbasis bagi hasil pada Koperasi-koperasi (BMT) yang tergabung pada PBMTI Jepara, dari tiga aspek yaitu dari aspek internal, aspek eksternal, dan dari aspek regulasi.

\section{Internal}

Pada aspek internal, hampir semua responden dalam penelitian ini memberikan pendapat yang sama tentang apa saja yang menjadi penyebab rendahnya pembiayaan bagi hasil pada BMT, yaitu dari segi faktor resiko yang tinggi. Adapun hasil dari penelitian ini terdapat beberapa faktor penyebab dari aspek internal BMT diantaranya:

\section{Resiko yang tinggi (high risk)}

Resiko yang tinggi merupakan masalah utama yang menyebabkan rendahnya pembiayaan berbasis bagi hasil pada BMT. BMT selaku pemilik modal sangat menghindari resiko, BMT takut terhadap ketidakpastian yang akan terjadi sehingga menyebabkan BMT harus menanggung kerugian besar. Karena dalam pembiayaan berbasis bagi hasil terdapat resiko- resiko yang mungkin akan terjadi. Maka dari itu BMT ingin meminimalir resiko-resiko yang ada pada pembiayaan bagi hasil dengan mengalihkan ke pembiayaan non-bagi hasil (murabahah). 
Karena resiko di dalam pembiayaan non-bagi hasil lebih rendah dibandingkan resiko yang ada pada pembiayaan bagi hasil.

\section{Kualitas dan kuantitas sumber daya insani yang kurang memadai}

Kurangnya pengalaman dan keahlian SDI merupakan masalah yang terjadi pada BMT. Hal tersebut disebabkan karena hampir semua SDI yang ada bukan berasal dari dasar lulusan ekonomi Islam. Apalagi sebagian besar SDI merupakan lulusan umum yang tidak pernah mengenyam pendidikan keagamaan, otomatis SDI yang ada belum memiliki kemampuan khusus selayaknya Islamic banker dalam menangani, memproses dan mengawasi pembiayaan berbasis bagi hasil.

Karena memang untuk SDI dari BMT yang betul-betul mengerti itu terkait sistem ekonomi syariah itu sangat jarang sekali.

Selain itu dari segi kuantitas juga SDI BMT masih kurang, jumlah SDI BMT yang dapat menangani pembiayaan bagi hasil dengan baik dan benar sangat minim, sehingga ketika anggota datang untuk mengajukan pembiayaan maka tidak dapat diproses dengan cepat.

\section{Penanganan pembiayaan berbasis bagi hasil rumit}

Penanganan pembiayaan berbasis bagi hasil ini tidak semudah penanganan pembiayaan non-bagi hasil. Karena dalam pembiayaan nonbagi hasil (murabahah) pihak BMT lebih pasti dalam menentukan harga dan keuntungan yang akan didapat. Sedangkan dalam pembiayaan berbasis bagi hasil peran BMT hanya sebagai shahibul maal atau pemilik modal, keterbatasan peran BMT sebagai investor. Penanganan pembiayaan berbasis bagi hasil yang rumit menyebabkan BMT enggan untuk menggunakan atau menawarkan pembiayaan bagi hasil ini kepada Anggota, ketika penanganan pembiayaan murabahah lebih mudah maka BMT akan mengalihkan segala macam bentuk pembiayaan ke akad murabahah. Karena ketika penanganan yang rumit, maka otomatis akan memerlukan biaya penanganan yang besar pula.

\section{Tidak adanya inovasi produk di dalam pembiayaan berbasis bagi hasil}

Kurangnya pengembangan produk pembiayaan bagi hasil mengakibatkan pembiayaan bagi hasil ini selalu kalah dibandingkan pembiayaan non-bagi hasil, pembiayaan non-bagi hasil murabahah selain lebih mudah untuk ditangani juga lebih pasti. Selain itu juga BMT kurang serius pada pembiayaan bagi hasil ini sehingga pembiayaan ini tidak berkembang. Padahal pembiayaan bagi hasil ini seharusnya dapat lebih unggul dan efektif dalam aplikasinya sehingga pembiayaan bagi hasil ini dapat meningkatkan sektor produktif di BMT itu sendiri dan dapat menumbuhkan perkembangan ekomomi masyarakat. 


\section{Terjadinya Asymmatric information}

Faktor yang mempengaruhi rendahnya pembiayaan berbasis bagi hasil selanjutnya adalah asymmatric information. Hal ini terjadi karena perbedaan informasi yang didapatkan antara pihak BMT dan Anggota, dalam hal ini Anggota lebih banyak mengetahui tentang kondisi usaha yang dijalankannya dibandingkan dengan pihak BMT. Sehingga kemungkinan terjadinya penyimpangan oleh Anggota sangatlah besar. Hal ini menjadi masalah bagi BMT karena dalam pembiayaan berbasis bagi hasil ini seharusnya ada transparansi diantara kedua belah pihak, sehingga Anggota tidak hanya melaporkan kerugian saja dan memanipulasi keuntungan sehingga BMT akan mengalami kerugian.

\section{Kurangnya sosialisasi kepada masyarakat terkait pembiayaan bagi hasil}

Faktor keenam yang menyebabkan rendahnya pembiayaan berbasis bagi hasil adalah kurangnya sosialisasi pihak BMT kepada masyarakat. Pihak BMT seharusnya melakukan sosialisasi agar masyarakat mengerti dan paham bahwa sistem bagi hasil yang ada di BMT berbeda dengan sistem bunga pada bank konvensional. BMT sudah seharusnya melakukan sosialisasi tentang sistem yang ada pada BMT. Karena masyarakat sangat berperan penting dalam pembiayaan berbasis bagi hasil di BMT.

\section{Eksternal Bank}

Pada aspek Eksternal bank (Anggota) dari hasil wawancara dengan responden terdapat tiga masalah pokok utama rendahnya pembiayaan bagi hasil di BMT, diantaranya:

\section{Adanya Moral Hazard}

Pada aspek Anggota, masalah pertama yang menyebabkan rendahnya pembiayaan berbasis bagi hasil adalah aspek moral hazard, di mana pengusaha enggan menyampaikan laporan keuangan dan menyembunyikan keuntungan yang sebenarnya. Hal ini menjadi masalah karena ketidakjujuran Anggota karena tidak mau berbagi keuntungan dengan BMT. Selain itu BMT juga mengkhawatirkan penyalahgunaan dana akibat dari sifat ketidakjujuran Anggota. Karena ketika dana diberikan bisa saja Anggota menggunakan dananya untuk keperluan lain. Dalam hal ini faktor moral hazard memiliki pengaruh yang sangat tinggi terkait rendahnya pembiayaan berbasis bagi hasil pada BMT.

\section{Rendahnya Pemahaman Masyarakat Terkait Pembiayaan Bagi Hasil}

Penyebab rendahnya pembiayaan bagi hasil pada BMT yang kedua yaitu pada faktor kurangnya pemahaman masyarakat terkait pembiayaan bagi hasil sehingga menyebabkan masyarakat tidak mengerti terkait 
sistem pembiayaan yang ada di BMT. Masyarakat masih menganggap bahwa BMT sama saja dengan bank konvensional. Sehingga masyarakat yang sudah terbiasa dengan bank konvensional enggan untuk beralih ke BMT. Kurangnya pemahaman masyarakat ini sangat mempengaruhi pertumbuhan atau perkembangan pembiayaan bagi hasil di BMT. BMT dapat melakukan sosialisasi-sosialisasi yang lebih kompleks lagi kepada masyarakat agar masyarakat dapat benar-benar paham terkait sistem pembiayaan di BMT. Karena peran masyarakatlah yang sangat penting, ketika masyarakat sudah paham pada BMT maka masyarakat pasti akan memilih BMT.

\section{Rendahnya Permintaan dari Anggota}

Faktor penyebab rendahnya pembiayaan bagi hasil yang ketiga adalah dari faktor permintaan dari Anggota itu sendiri yang rendah. Jadi hal ini mungkin dapat disebabkan oleh beberapa sebab apakah mungkin karena Anggota kurang berminat, atau Anggota tidak mau berbagi hasil dengan BMT/tidak mau membagi keuntungannya dengan BMT, atau mungkin juga karena Anggota tidak mengerti terkait pembiayaanpembiayaan yang ada pada BMT atau bisa jadi juga karena Anggota masih menganggap bahwa BMT sama saja dengan koperasi konvensional. Selain itu faktor kebutuhan Anggota juga berpengaruh, karena permintaan Anggota sesuai kebutuhan.

\section{Regulasi}

Pada sudut pandang regulasi, faktor rendahnya pembiayaaan bagi hasil pada BMT disebabkan kurangnya dukungan dari regulator. Untuk meningkatkan pembiayaan bagi hasil di BMT ini diperlukan kebijakankebijakan pendukung dari pihak regulator. Regulator tidak melarang pembiayaan berbasis bagi hasil ini, hanya saja regulator kurang tegas dengan memberi kebijakan-kebijakan pendukung seperti berapa persen ketetapan untuk pembiayaan berbasis bagi hasil. Kalau tidak adanya kebijakan atau regulasi maka pihak bank tidak mau memikirkan hal itu dengan serius. Pihak BMT akan terus menggunakan pembiayaan non-bagi hasil yang lebih pasti dan rendah resiko.

\section{Analisis Data}

Hasil dari penelitian ini menunjukkan bahwa terdapat beberapa faktor yang menyebabkan rendahnya pembiayaan berbasis bagi hasil seperti diilustrasikan dalam Tabel 4 berikut.

\section{Tabel 4}

Rekapitulasi Persepsi Responden terhadap Rendahnya Pembiayaan Berbasis bagi Hasil

\begin{tabular}{|c|c|c|c|c|}
\hline & Aspek & Manager & Nasabah & Akademisi \\
\hline
\end{tabular}


Analisis Kritis Atas Rendahnya Pembiayaan Berbasis Bagi Hasil Pada Bmt di Jepara

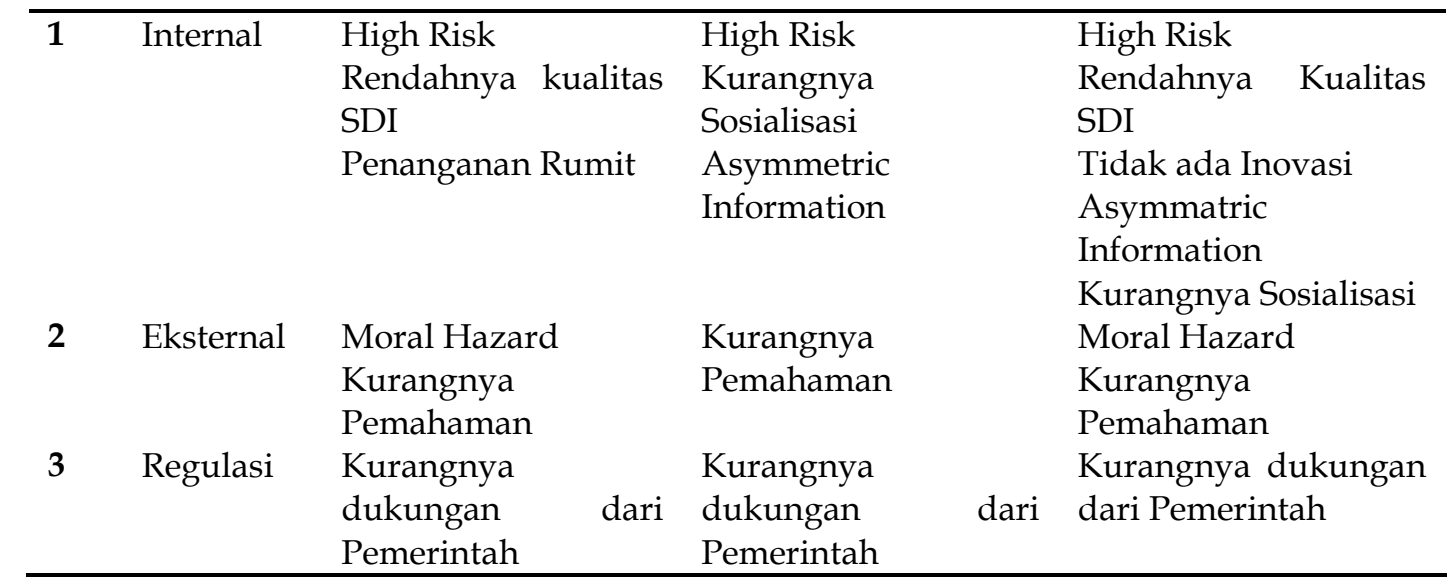

Tabel 4 menunjukkan bahwa dari aspek internal BMT, penyebab rendahnya pembiayaan berbasis bagi hasil pada BMT yang paling mendominasi adalah faktor resiko yang tinggi (high risk). Akan tetapi sebenarnya, jika dilihat lebih jelas lagi, faktor tersebut bukanlah alasan BMT untuk meninggalkan pembiayaan bagi hasil, pembiayaan bagi hasil dapat diperbaiki dengan cara pihak BMT diharapkan melakukan pengembangan dan inovasi-inovasi pada produk bagi hasil agar resiko pada pembiayaan bagi hasil dapat diminimalisir dan nasabah akan lebih tertarik dan berminat sehingga pembiayaan bagi hasil akan lebih meningkat di BMT. Hal lain yang dapat dilakukan BMT juga dengan melakukan berbagai proses sosialisasi, pengenalan produk pembiayaan bagi hasil kepada masyarakat agar masyarakat lebih memahami dan mengerti. Karena sebenarnya jika kedua belah pihak antara pihak BMT dan nasabah sudah betul-betul paham terkait pembiayaan berbasis bagi hasil ini maka pembiayaan bagi hasil ini akan dapat berkembang dan mendominasi di BMT.

Pada aspek eksternal, rendahnya pemahaman masyarakat dapat diatasi dengan cara masyarakat diharapkan mencari tahu dan lebih memahami lagi terkait produk bagi hasil pada BMT dengan mengikuti sosialisasi-sosialisasi yang dilakukan oleh Koperasi syariah. Karena sebenarnya jika masyarakat telah mengerti produk bagi hasil BMT ini pasti masyarakat akan paham bahwa sistem syariah berbeda dengan sistem konvensional.

Pada Aspek regulasi, dukungan dari para regulator sangat dibutuhkan dalam perkembangan pembiayaan bagi hasil ini. Para regulator koperasi syariah, Kementrian Koperasi misalnya diharapkan dapat mengeluarkan kebijakan-kebijakan pendukung seperti menetapkan aturan bahwa setiap Koperasi syariah harus mengeluarkan porsi pembiayaan bagi hasil dengan persentase di atas 50\% dari porsi pembiayaan lainnya. Hal tersebut dilakukan untuk mendorong pembiayaan berbasis bagi hasil di BMT agar dapat lebih meningkat dan 
mendominasi. Dan pada akhirnya akan menggerakkan sektor riil karena pembiayaan yang diberikan berupa modal usaha yang bersifat produktif.

\section{KESIMPULAN}

Rendahnya pembiayaan berbasis bagi hasil disebabkan oleh 3 aspek yakni, aspek internal BMT, masalah rendahnya pembiayaan berbasis bagi hasil disebabkan oleh enam faktor, yaitu: resiko yang tinggi (High risk), kualitas dan kuantitas SDI yang kurang memadai, penanganaan yang rumit, tidak adanya inovasi produk, asymmetric information, dan kurangnya sosialisasi kepada masyarakat. Dari enam faktor internal BMT, faktor yang paling mendominasi adalah high risk. Tingginya resiko pembiayaan bagi hasil menyebabkan pembiayaan dengan akad non-bagi hasil murabahah yang mendominasi di Koperasi syariah. Aspek eksternal BMT (anggota), masalah rendahnya pembiayaan berbasis bagi hasil disebabkan oleh tiga faktor, yaitu: kurangnya pemahaman masyarakat, moral hazard, dan permintaan sedikit. Dalam aspek ini, yang menjadi penyebab utama rendahnya pembiayaan berbasis bagi hasil adalah faktor kurangnya pemahaman masyarakat terkait pembiayaan bagi hasil di Koperasi syariah. Sehingga menyebabkan masyarakat yang sudah terbiasa dengan bank konvensional enggan untuk beralih ke Koperasi syariah. Aspek regulasi, masalah rendahnya pembiayaan berbasis bagi hasil disebabkan oleh faktor kurangnya dukungan dari regulator. Hal ini tercermin dari tidak adanya kebijakan- kebijakan pendukung dalam pembiayaan bagi hasil ini sehingga menyebabkan porsi pembiayaan berbasis bagi hasil di koperasi syariah selalu lebih rendah .

Solusi dan strategi atas rendahnya pembiayaan berbasis bagi hasil dari penelitian ini adalah bahwa untuk aspek internal BMT, pihak BMT seharusnya lebih memperhatikan lagi pembiayaan bagi hasil ini dengan melakukan pengembangan atau inovasi pada produk pembiayaan bagi hasil agar resiko-resiko yang ada pada pembiayaan bagi hasil dapat diminimalisir, kemudian juga diharapkan kepada BMT untuk melakukan sosialisasi-sosiasliasi yang lebih merata kepada masyarakat agar masyarakat paham dan mengerti terkait pembiayaan berbasis bagi hasil di Koperasi syariah.

Untuk Anggota BMT, hendaknya lebih memahami lagi terkait sistem yang ada pada koperasi syariah, Karena sebenarnya kalau masyarakat sudah paham, maka masyarakat akan tahu bahwa sistem koperasi syariah berbeda dengan sistem konvensional dan masyarakat akan lebih memilih koperasi syariah. Karena di dalam pembiayaan bagi hasil ini terdapat keadilan, keuntungan dan kerugian di tanggung bersama. Untuk para regulator diharapkan dapat lebih kompleks lagi dalam melakukan pengawasan kepada Koperasi syariah terkait pembiayaan berbasis bagi hasil. Selain itu para regulator juga seharusnya mengeluarkan kebijakan- 
kebijakan pendukung seperti menetapkan aturan terkait berapa besarnya persentase pembiayaan berbasis bagi hasil yang harus ada di lembaga syariah untuk mendorong peningkatan pembiayaan bagi hasil sehingga kehadiran koperasi syariah akan lebih mensejahterakan Ekonomi Umat.

\section{DAFTAR PUSTAKA}

Ascarya. (2013). Akad dan Produk Bank Syariah, Jakarta: Rajagrafindo persada.

Ascarya, Diana Yumanita. (2005). Mencari Solusi Rendahnya Pembiayaan Bagi Hasil Di Perbankan Syariah Indonesia, Buletin Ekonomi Moneter Dan Perbankan.

Hana, K. F. (2018). Faktor-Faktor Yang Mempengaruhi Keputusan Non Muslim Menjadi Anggota Pada KSPPS Fastabiq Khoiru Ummah Pati. MALIA: Journal of Islamic Banking and Finance, 2(2), 189-200. Retrieved from http://journal.stainkudus.ac.id/index.php/syirkah/index

Muhamad. (2017). Sistem Bagi Hasil dan Pricing Bank Syariah, Yogyakarta: UII Press.

Muhammad. (2004). Teknik Perhitungan Bagi Hasil dan Pricing di Bank Syariah, Yogyakarta: UII Press.

Muhammad. (2005). Konstruksi Mudharabah Dalam Bisnis Syariah, Yogyakarta: BPFE.

Pamungkas Aji P. (2013). Identifikasi Factor Yang Mempengaruhi Rendahnya Pembiayaan Bagi Hasil Perbankan Syariah, Skripsi, jurusan Ilmu Ekonomi Fakultas Brawijaya Malang.

Safi'i Antonio M. (2001). Bank Syariah: Dari Teori ke Praktek, Jakarta: Gema Insani Press.

Safi'i Antonio M. dkk. (2018). Islamic Business Management, Yogyakarta: BPFE.

Susana Erni, Anisa Prasetyanti. (2011). Pelaksanaan dan Sistem Bagi Hasil Pembiayaan Al-Mudharabah pada Bank Syariah, Jurnal Keuangan dan Perbankan, Universitas Merdeka Malang, Vol.15, No.3.

Kartika Soetopo dkk. (2010). Analisis Implementasi prinsip Bagi Hasil, Resiko dan Penanganan Pembiayaan bermasalah terhadap pembiayaan Musyarakah dan Pembiayaan Murabahah.

Wiroso. (2005). Penghimpunan Dana dan Distribusi Hasil Usaha Bank Syariah, Jakarta: PT. Grasindo, hlm: 120. 
Halaman ini sengaja dikosongkan 